\title{
Potential of phosphate solubilizing fungi isolated from peat soils as inoculant biofertilizer
}

\author{
DENI ELFIATI ${ }^{1, \bullet}$, DELVIAN $^{1}$, HAMIDAH HANUM ${ }^{2}$, ARIDA SUSILOWATI ${ }^{1}$, HENTI HENDALASTUTI RACHMAT $^{3}$ \\ ${ }^{1}$ Faculty of Forestry, Universitas Sumatera Utara, Jl. Tridharma Ujung No. 1. Kampus USU, Medan 20155, North Sumatra, Indonesia \\ Tel.: +62-61-8220605, `email: denielfiati@yahoo.com \\ ${ }^{2}$ Faculty of Agriculture, Universitas Sumatera Utara. Jl. Prof. A. Syofyan No. 3, Kampus USU, Medan 20155, North Sumatra, Indonesia \\ ${ }^{3}$ Forest Research and Development Agency, Ministry of Environment and Forestry. Jl. Raya Gunung Batu, Pasir Jaya, Bogor 16118, West Java, Indonesia
}

Manuscript received: 6 July 2020. Revision accepted: 5 May 2021.

\begin{abstract}
Elfiati D, Delvian, Hanum H, Susilowati A, Rachmat HH. 2021. Potential of phosphate solubilizing fungi isolated from peat soils as inoculant biofertilizer. Biodiversitas 22: 3042-3048. Phosphate-solubilizing fungi are the microbes that have the ability to dissolve insoluble phosphate and made it available for plants. Therefore, the purpose of this study was to obtain the phosphatesolubilizing fungi from peat soils. Peat soil samples were taken in a composite at a depth $0-20 \mathrm{~cm}$ from the peat ecosystem in Nagasaribu Village, Lintong Nihuta Sub-district, Humbang Hasundutan District, North Sumatra, Indonesia. Soil samples were isolated to obtain phosphate-solubilizing fungi using the Pikovskaya selective medium. The obtained isolates were tested for their ability to dissolve phosphate qualitatively by calculating the dissolution index values and quantitatively by calculating the available phosphorus on Pikovskaya medium by using four phosphate sources, namely $\mathrm{Ca}_{3}\left(\mathrm{PO}_{4}\right)_{2}, \mathrm{AlPO}_{4}, \mathrm{FePO}_{4}$, and phosphate rock. Total of 12 isolates of phosphate-solubilizing fungi was obtained during the present study. Based on the results of qualitative and quantitative testing, all 12 isolates have the ability to release phosphate from the four tasted phosphate sources. The qualitative test obtains dissolution index values that vary from 2.55 to 4.25 , while quantitatively, the isolates were able to dissolve phosphate in the value range from $17.77 \mathrm{ppm}$ to 69.86 ppm. The top five fungal isolates with highest phosphate-solubilizing potential were FG5, FG8, FG9, FG11, and FG12. Based on molecular identification, these five isolates were identified as Aspergillus niger.
\end{abstract}

Keywords: Aspergillus niger, peat soil, phosphorus, phosphate- solubilizing fungi, phosphate source

\section{INTRODUCTION}

Phosphorus $(\mathrm{P})$ is an essential macronutrient required for plant cell development, the formation of fine roots, flowers, fruits, and seeds as well as the accumulation and energy release (Walpola and Yon 2012). Phosphorus is absorbed by plants in the form of orthophosphate. The availability of $\mathrm{P}$ nutrients in soil is generally low due to its binding process or fixation, where it is bound to be $\mathrm{Fe}$ phosphate and Al-phosphate in acidic soils or Caphosphate in alkaline soils (Chang and Yang 2009; Oliveira et al. 2009; Malviya et al. 2011; Tallapragada and Seshachala 2012; Sharma et al. 2012; Hou et al. 2018). Phosphorus deficiency can cause disruption of plant root growth, especially fine roots inhibits the absorption of nutrients, thus limiting plant growth.

Plants cannot absorb phosphorus in the bound form, which must be converted into simpler form before make available to plants. Soil microbes such as fungi and bacteria have the ability to change insoluble and bound phosphate into a soluble form that can be absorbed by plants (Rodriguez and Fraga 1999; Chatli et al. 2008; Chang and Yang 2009; Malviya et al. 2011; Das et al. 2013; Sharma et al. 2013). Phosphate-solubilizing fungi of the genus Penicillium, Aspergillus, Fusarium, and Sclerotium are commonly known for their ability to dissolve insoluble nutrients including phosphorus with high effectiveness (Whitelaw 2000; Pradhan and Sukla 2005; El-Azouni
2008; Malviya et al. 2011; Elias et al. 2016; Gizaw et al. 2017).

Phosphate-solubilizing fungi can be used as biological fertilizers, but screening process is necessary to obtain effective isolates (Bashan et al. 2013; Sharma et al. 2013). In comparison to bacteria, fungi have been reported to have higher ability to dissolve P (Nahas 1996). Many of the dominant fungal groups grow in acid soils, such as peat soils can be used as a source to obtain phosphatesolubilizing fungi isolates.

The total area of peat lands in Indonesia is estimated about 18.4 million ha, spread over Sumatra, Kalimantan, Irian Jaya, and small portion in Sulawesi. In North Sumatra, there are around 0.325 million ha (Mha) or around $1.8 \%$ of the total peat land area in Indonesia (Soekardi and Hidayat 1988; Agus and Subiksa 2008). In North Sumatra, peat areas are spread across several districts, namely Humbang Hasundutan, Langkat and Mandailing Natal.

Peat soils are formed due to high accumulation of dead organic material that has undergone humification but low in mineralization process. The peat ecosystem consists of low $\mathrm{pH}$ and anaerobic conditions, which leads to slow of its organic matter. The level acidity of peat is relatively high with a $\mathrm{pH}$ range 3-5. Thicker peat horizon having lower bases and the reaction of the soil becomes more acidic. Peat thickness positively correlated with the level of cation exchange capacity but inversely has negative correlation 
with base saturation. Thicker peat having higher cation capacity and lower bases caused acidification in the soil. Acidic soils affect the availability of low nutrients. Peatlands is a unique ecosystem (Nurulita et al. 2016) with soils rich in organic matter which is a source of macro and micronutrients for plant and a source of energy and carbon for heterotrophic soil microbes. In various ecosystems, microbes play an active role in determining the availability of nutrients for plant growth. Thus, it is necessary to explore microbes especially phosphate-solubilizing fungi that are beneficial for plant growth. The information of phosphate-solubilizing fungi in peatland soils has not been studied deeply, therefore, the purpose of this study was to obtain phosphate-solubilizing fungi from peat soils that have high potential in dissolving phosphate.

\section{MATERIALS AND METHODS}

\section{Study site and soil sampling}

The study site used for soil sampling in the present study was within the Nagasaribu Village, Lintongnihuta Sub-district, Humbang Hasundutan District, North Sumatra. Geographically it was located between $2^{\circ} 15^{\prime} 093^{\prime}$ $\mathrm{N}$ and $98^{\circ} 53^{\prime} 442^{\prime \prime} \mathrm{E}$. The peatlands were found fibric in mature and located at 1414 meters above sea level. Soil samples were taken diagonally at a depth of 0-20 cm in six plots measuring $20 \mathrm{~m}$ x $20 \mathrm{~m}$ for five points. Samples were collected in zipped plastic bags and taken to the laboratory for microbial isolation and analysis of organic $\mathrm{C}$ content, available $\mathrm{P}$, and $\mathrm{pH}$ values.

\section{Isolation of phosphate-solubilizing fungi}

Phosphate-solubilizing fungi were isolated following the method used by Panda et al. (2016). Ten (10) g of soil was taken in $250 \mathrm{~mL}$ Erlenmeyer flask containing $90 \mathrm{~mL}$ $\mathrm{NaCl}(0.85 \%)$ then shaked for 30 minutes. Serial dilution was made until reaching the concentration of $10^{-5}$. One mL of resultant solution was pipetted out from each of $10^{-3}, 10$ ${ }^{4}$, and $10^{-5}$ serial dilution, poured out in sterilized petri dish containing $12 \mathrm{~mL}$ Pikovskaya agar medium (composition per liter distilled water: glucose $10 \mathrm{~g} ; \mathrm{Ca}_{3}\left(\mathrm{PO}_{4}\right)_{2} 5 \mathrm{~g}$; $\left(\mathrm{NH}_{4}\right)_{2} \mathrm{SO}_{4} 0,5 \mathrm{~g} ; \mathrm{KCl} 0,2 \mathrm{~g} ; \mathrm{MgSO}_{4} .7 \mathrm{H}_{2} \mathrm{O} 0,1 \mathrm{~g} ; \mathrm{MnSO}_{4}$ $0,002 \mathrm{~g} ; \mathrm{FeSO}_{4} 0,002 \mathrm{~g}$; yeast extract $0,5 \mathrm{~g}$; agar $20 \mathrm{~g}$ ) and incubated with upside-down position at $28-30^{\circ} \mathrm{C}$ for 3 days. The growth of phosphate-solubilizing fungi was indicated by the formation of clear zone surrounding the fungal colony. Fungal purification was conducted in cultivating the fungi into fresh culture medium and transferred to test tubes containing Pikovskaya medium and stored at $4^{\circ} \mathrm{C}$ prior to further process.

\section{Qualitative testing of Pikovskaya solid medium}

Purified phosphate-solubilizing fungal isolates were tested for their ability to release phosphate on solid Pikovskaya medium with phosphorus source $\mathrm{Ca}_{3}\left(\mathrm{PO}_{4}\right)_{2}$, $\mathrm{AlPO}_{4}, \mathrm{FePO}_{4}$, and phosphate rocks. The test medium was put into a petri dish and inoculated with purified fungal isolates, then incubated for five days at room temperature. Qualitative phosphate solubilizing activity of fungi was calculated by using a phosphate solubility index i.e. ratio between the diameter of the clear zone plus the diameter of the colony to the diameter of the colony (Yasmin and Bano 2011; Mardat et al. 2014; Yasser et al. 2014; Elias et al. 2016).

\section{Quantitative testing on Pikovskaya liquid medium}

One hundred (100) $\mathrm{ml}$ of Pikovskaya liquid medium (adjusted $\mathrm{P}$ source ie $\mathrm{Ca}_{3}\left(\mathrm{PO}_{4}\right)_{2}, \mathrm{AlPO}_{4}, \mathrm{FePO}_{4}$, and phosphate rocks) was inoculated with phosphatesolubilizing fungi and incubated for seven days at $28^{\circ}$ $30^{\circ} \mathrm{C}$. After that, the culture was centrifuged at $6000 \mathrm{rpm}$ for 10 minutes until filtrate was separated from its spore and hyphae. The clear filtrate was determined to provide $\mathrm{P}$ levels by the colorimetric method and measured by a spectrophotometer. The experiment was repeated thrice and the isolates were selected based on the ability of the phosphate-solubilizing fungi to dissolve $\mathrm{P}$ on the medium by averaging the three replications. Control was determined as medium without fungi inoculation. The $\mathrm{pH}$ of medium was measured to determine the effect of phosphate dissolution by fungi on the $\mathrm{pH}$ of medium (Gao et al. 2016).

\section{Analysis of organic acids}

Phosphate-solubilizing fungi were inoculated in $100 \mathrm{ml}$ of Pikovskaya liquid medium and incubated at $28^{\circ}-30^{\circ} \mathrm{C}$ for three days with a constant shaking of $100 \mathrm{rpm}$. At the end of the incubation period, the culture was centrifuged at a speed of $1000 \mathrm{rpm}$ at $25^{\circ} \mathrm{C}$ for 20 minutes. The resultant was then filtered with milipore, and used to determine organic acid levels. Determination was done by HighPerformance Liquid Chromatography (Shimadzu Liquid Chromatography LC-3A). Organic acids produced by fungi were compared with standard values from six types of acids namely citric acid, oxalic acid, malic acid, acetic acid, butyric acid, and lactic acid.

\section{Analysis of indole acetic acid}

Indole-3-acetic acid (IAA) synthesized by each fungal isolate was measured following the methods used by Bric et al. (1991). Fungal isolates were grown in $100 \mathrm{~mL}$ nutrient broth having 0, 50, 100, 200, 400 and $500 \mu \mathrm{g} / \mathrm{mL}$ tryptophan. Fungal cultures were grown for 3 days at $28^{\circ} \mathrm{C}$ and centrifuged at $3000 \mathrm{rpm}$ for $30 \mathrm{~min}$. The supernatant $(2$ $\mathrm{mL}$ ) was mixed with two drops of orthophosphoric acid and $4 \mathrm{~mL}$ of the Salkowski reagent. The presence of pink color indicates that the isolate produces IAA. The absorbance of developed pink color is read at $530 \mathrm{~nm}$ with the help of spectrophotometer Spectronic 20 D. The IAA concentration was determined using a calibration curve of pure IAA as a standard.

\section{Identification of potential phosphate-solubilizing fungi}

The five isolates of phosphate-solubilizing fungi with the high ability to dissolve phosphate quantitatively were identified morphologically and molecularly. Morphological identification was carried out up to genus level by determining the macroscopic and microscopic characteristics (Gilman 1971; Gandjar et al. 1999). Fungi 
were grown on potato dextrose agar (PDA) and incubated for 3 days at $28^{\circ} \mathrm{C}$. Molecular identification was done by using ITS 1 rDNA primers and ITS 4 primers according to White et al. (1990). Isolation of fungal genomic DNA followed the technical procedure given by DNeasy Plant Mini kit, amplification of fungal 5.8S rDNA was performed on ITS-rDNA region using ITS1 and ITS4 primers with a reaction mixture containing of Go Taq master mix solution, DNA template, each primer, and nuclease-free water. PCR products were then purified and Sanger-sequenced (First Base Sequencing Service, Singapore). Similarity searches were conducted by using the Basic Local Alignment Search Tool-nucleotide (BLASTn) program in the National Center for Biotechnology Information (NCBI) GenBank database.

\section{RESULTS AND DISCUSSION}

\section{Isolation and qualitative testing of phosphate- solubilizing fungi}

The population of phosphate-solubilizing fungi was 2.86 colonies forming unit (CFU) per $\mathrm{g}$ of soils. This fungal population is classified as quite high based on the population of phosphate-solubilizing microbes in the soil ranges from $10^{4}$ to $10^{6} \mathrm{CFU}$ per $g$ of soil (Gaur et al. 1980). The presence of phosphate-solubilizing fungi is related to the content of organic matter in the soil as an energy source and carbon source, thus affecting the amount and activity. Soil analysis determined that organic $\mathrm{C}$ content in peat soil was $38.77 \%$ (classified as very high) with acidic $\mathrm{pH}$ (4.53), while the occurrence of soluble $\mathrm{P}$ was categorized as low (12.69 ppm). Acid soils are suitable habitats for fungi because fungi are dominant in acid soils (Havlin et al. 1999).

The isolation resulted in 12 phosphate-solubilizing fungi isolates. All isolates formed a clear zone around the colony (Figure 1), indicating of solubilization of phosphate source used. Furthermore, twelve isolates were selected qualitatively by calculating the solubility index values (Table 1). All isolates showed their ability to dissolve phosphate from $\mathrm{Ca}_{3}\left(\mathrm{PO}_{4}\right)_{2}, \mathrm{AlPO}_{4}, \mathrm{FePO}_{4}$, and phosphate rock sources with varying values.

If the solubility index values are higher, qualitatively the ability of isolated fungi to dissolve $\mathrm{P}$ will also be higher. The solubility index value varies from 2.55 for dissolving $\mathrm{FePO}_{4}$ compounds to 4.25 for dissolving $\mathrm{AlPO}_{4}$ compounds. Rashid et al. (2004) found that the solubility index varies from 2.16 to 3.3, while Mahamuni et al. (2012) obtained a solubility index phosphate-solubilizing fungi isolated from rhizosphere sugarcane and sugar beet range between 1.13 to 1.59 . Elias et al. (2016) reported that solubility index ranging from 1.10 to 3.05 . Islam et al. (2019) also reported solubility index ranged between 1.42 to 2.24 for the fungal culture isolated from subtropical soils in Okinawa. The difference in solubility index values may be due to differences in the amount, type, and diffusion rate of organic acids released by the fungal isolates. Phosphate dissolution is related to ability of the fungi to release organic acids. Strong correlation has been reported the correlation between solubility index and organic acids produce (Alam et al. 2002; Das et al. 2013; Islam et al. 2019).

\section{Quantitative testing on Pikovskaya liquid medium}

The results of the ability of phosphate-solubilizing fungi to dissolve $\mathrm{P}$ derived from $\mathrm{Ca}_{3}\left(\mathrm{PO}_{4}\right)_{2}, \mathrm{AlPO}_{4}, \mathrm{FePO}_{4}$, and phosphate rocks and the $\mathrm{pH}$ of medium can be seen in Table 2. All isolated fungi have the ability to dissolve $\mathrm{P}$ from all $\mathrm{P}$ sources test, however, the ability of fungi to dissolve phosphate varies among isolates. According to Yadav et al. (2011a), the ability to dissolve P can vary even the same fungi species.

The ability of phosphate-solubilizing fungi to dissolve $\mathrm{P}$ was different for each source. The greatest effect of dissolving $\mathrm{P}$ was found in the medium containing $\mathrm{Ca}_{3}\left(\mathrm{PO}_{4}\right)_{2}$, followed by $\mathrm{FePO}_{4}, \mathrm{AlPO}_{4}$, and phosphate rock. The amount of $\mathrm{P}$ dissolved ranged between $36.41-69.86$ ppm, 22.45 - 58.77 ppm, 25.80 - 59.64 ppm, and 17.77 40.77 ppm from $\mathrm{Ca}_{3}\left(\mathrm{PO}_{4}\right)_{2}, \mathrm{FePO}_{4}, \mathrm{AlPO}_{4}$, and phosphate rock respectively. This is because $\mathrm{FePO}_{4}, \mathrm{AlPO}_{4}$, and phosphate rock have complex structure than $\mathrm{Ca}_{3}\left(\mathrm{PO}_{4}\right)_{2}$. Previous studies reported that the solubilization of $\mathrm{Ca}_{3}\left(\mathrm{PO}_{4}\right)_{2}$ was the highest, followed by $\mathrm{AlPO}_{4}$ and $\mathrm{FePO}_{4}$ (Hue et al. 1986; Vassileva et al. 1998; Kang et al. 2002; Gupta et al. 2007; El-Azouni 2008; Zang et al. 2018; Islam et al. 2019).

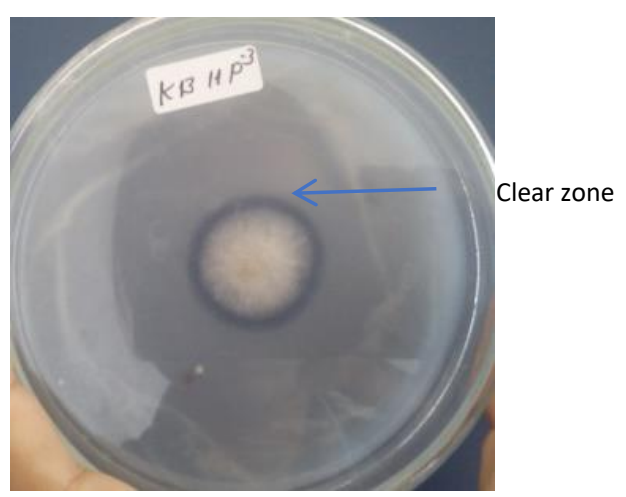

Figure 1. Clear zone around phosphate-solubilizing fungi colony

Table 1. Solubility index of phosphate-solubilizing fungi with four phosphate source

\begin{tabular}{ccccc}
\hline \multirow{2}{*}{$\begin{array}{c}\text { Isolate } \\
\text { code }\end{array}$} & Ca3(PO4) & AlPO4 & FePO4 & $\begin{array}{c}\text { Phosphate } \\
\text { rock }\end{array}$ \\
\cline { 2 - 5 } & 3.69 & 2.93 & 2.77 & 2.77 \\
FG1 & 3.30 & 3.17 & 2.75 & 2.81 \\
FG2 & 2.90 & 3.14 & 3.12 & 2.89 \\
FG3 & 3.18 & 3.56 & 2.55 & 2.80 \\
FG4 & 3.08 & 4.25 & 3.08 & 3.38 \\
FG5 & 3.34 & 2.81 & 3.50 & 2.90 \\
FG6 & 3.26 & 3.38 & 3.13 & 3.21 \\
FG7 & 2.87 & 3.22 & 2.86 & 3.34 \\
FG8 & 2.88 & 3.56 & 3.35 & 3.22 \\
FG9 & 3.24 & 3.04 & 2.65 & 2.76 \\
FG10 & 3.32 & 4.24 & 3.21 & 2.98 \\
FG11 & 3.63 & 3.18 & 3.77 & 3.81 \\
FG12 & & & & \\
\hline
\end{tabular}


Table 2. Dissolution of phosphate (ppm) by phosphate-solubilizing fungi from four phosphate source

\begin{tabular}{|c|c|c|c|c|c|c|c|c|}
\hline \multirow[b]{2}{*}{ Isolate code } & \multicolumn{8}{|c|}{ Phosphate source } \\
\hline & $\mathrm{Ca}_{3}\left(\mathrm{PO}_{4}\right)_{2}$ & $\begin{array}{c}\text { pH of } \\
\text { medium }\end{array}$ & $\mathrm{FePO}_{4}$ & $\begin{array}{c}\text { pH of } \\
\text { medium }\end{array}$ & $\mathrm{AlPO}_{4}$ & $\begin{array}{c}\text { pH of } \\
\text { medium }\end{array}$ & $\begin{array}{c}\text { Phosphate } \\
\text { rock }\end{array}$ & $\begin{array}{c}\text { pH of } \\
\text { medium }\end{array}$ \\
\hline Control & 6.37 & 6.81 & 2.26 & 6.66 & 3.74 & 6.73 & 3.27 & 6.81 \\
\hline FG1 & 36.41 & 3.85 & 32.66 & 2.35 & 44.91 & 2.79 & 29.64 & 3.76 \\
\hline FG2 & 46.00 & 4.20 & 42.50 & 3.06 & 27.02 & 2.82 & 27.05 & 5.24 \\
\hline FG3 & 46.89 & 4.16 & 57.77 & 2.73 & 36.23 & 2.66 & 31.27 & 4.40 \\
\hline FG4 & 56.00 & 4.03 & 31.98 & 2.32 & 42.18 & 2.69 & 17.77 & 3.74 \\
\hline FG6 & 53.05 & 3.81 & 46.61 & 2.10 & 33.95 & 2.64 & 33.91 & 4.35 \\
\hline FG7 & 55.32 & 3.71 & 22.45 & 2.90 & 25.80 & 2.59 & 32.02 & 3.08 \\
\hline FG8 & 69.86 & 4.05 & 52.50 & 2.24 & 59.64 & 2.74 & 33.95 & 2.95 \\
\hline FG9 & 58.95 & 3.89 & 26.30 & 2.37 & 50.25 & 2.61 & 29.00 & 2.38 \\
\hline FG10 & 40.77 & 3.52 & 41.82 & 2.20 & 37.32 & 2.49 & 27.77 & 3.00 \\
\hline FG11 & 64.02 & 3.46 & 48.07 & 2.23 & 39.93 & 2.68 & 40.52 & 2.31 \\
\hline FG12 & 64.02 & 3.80 & 50.25 & 2.45 & 36.59 & 2.81 & 28.73 & 3.37 \\
\hline
\end{tabular}

Meanwhile, research by Zang et al. (2018) showed that the fungi isolated from the bamboo rhizosphere were higher at dissolving $\mathrm{P}$ from $\mathrm{AlPO}_{4}$ and $\mathrm{FePO}_{4}$ than $\mathrm{Ca}_{3}\left(\mathrm{PO}_{4}\right)_{2}$. The isolate FG8 showed highest potential to dissolve $\mathrm{P}$ from $\mathrm{Ca}_{3}\left(\mathrm{PO}_{4}\right)_{2}$ and $\mathrm{AlPO}_{4}$ sources. Similarly, isolate FG5 showed the highest solubility of $\mathrm{P}$ from $\mathrm{FePO}_{4}$ and isolate FG11 from phosphate rock. Studies on phosphate dissolving ability were carried out on phosphate rock source because direct application of phosphate rock showed less effective result in short period of time to most perennial plant (Goenadi et al. 2000). Gyaneshwar et al. (2002) determined that acid-producing microbes as that of phosphate-solubilizing fungi can increase the phosphate solubility in phosphate rock.

Phosphate dissolution followed by a decrease in $\mathrm{pH}$ of the medium was observed in the range $6.81-2.20$. The decreasing $\mathrm{pH}$ of medium has also been reported from previous studies. The Aspergillus genus showed the highest decrease in $\mathrm{pH}$ compared to other genera (Pradhan dan Suklan 2005; Khan et al. 2009; Das et al. 2013; Yasser et al. 2014; Acevedo et al.2014; Elias et al. 2016; Islam et al. 2019). The decrease in $\mathrm{pH}$ was caused by the production of organic acids during metabolic process of fungi. Fungi have been known to secrete various types of organic acids such as citric, oxalic, formic, and others (Illmer and Schinner 1995). Organic acids convert tricalcium phosphate to mono and dicalcium phosphate so that phosphorus nutrients became available to plants. Nahas (1996); Mardad et al. (2014); and Anand et al. (2016) showed that organic acids produced by fungi dissolve insoluble phosphate with a decrease in $\mathrm{pH}$, chelation of cations, and competition with phosphate on sorption sites in the soil. The research result of Omar (1998); Whitelaw (2000); and Chatli et al. (2008) who used bacteria and phosphate solubilizing fungi show that organic acids produce by microbial metabolism bound or chelate cations that bound $\mathrm{P}$, so that $\mathrm{P}$ solubility increases. According to Mahidi (2011) and Wei et al. (2018), the ability of organic acids to chelate a metal cation is strongly influenced by its molecular structure, especially by the number of carboxyl and hydroxyl groups. Besides the strength of the acid, the type and position of the ligand also determine its effectiveness in the dissolution process.

Based on the ability to dissolve phosphate compounds, five isolates were selected namely, FG5, FG8, FG9, FG11, and FG12 were the highest dissolving compound P. The five selected isolates consistently dissolved $\mathrm{P}$ from the four $\mathrm{P}$ sources used, including the high criteria (more than 26 ppm).

\section{The ability of isolates to produce organic acids}

Phosphate-solubilizing fungal isolates produce organic acids with different amounts and types (Table 3). Results of all the isolates indicated that butyric and oxalate acids were two major acids produce by all the tested phosphatesolubilizing fungi. The different amount and types of organic acids produce affect the ability of fungi to dissolve P. All fungi isolates produce butyric acid, eight fungi isolates produce citric acid, ten isolates produce oxalate acid, five isolates produce malic acid, eight isolates produce acetate acid, and four isolates produce lactate acid. Result of the present study is supported by the research of Rashid et al. (2004) who studied the production of organic acids by phosphate-solubilizing fungi. Five selected isolates (FG5, FG8, FG9, FG11, and FG12) produce citric, oxalate, and butyric acid. FG12 isolates also produce malic, acetate, and lactate acid, isolates FG5 and FG9 also produce malic and acetic acid, while isolates FG8 and FG11also produce acetic acid. The ability of organic acids to release $\mathrm{P}$ bonds is not the same as one another. Ryan et al. (2001); Hou et al. (2018) reported that citric acid dissolved $\mathrm{P}$ higher than oxalic and malic acid. Organic acids that are able to form a more stable complex with metal cations will be more effective in releasing aluminum and iron soil minerals so that they will release greater phosphorus. According to Whitelaw (2000), the ability of phosphate-solubilizing fungi to produce organic acids was ten times higher than that of bacteria. The $\mathrm{pH}$ value of the medium can decrease to $\mathrm{pH} 1$ or 2 . The ability to produce organic compounds is basically determined by genes, but 
also be influenced by environmental factors such as carbon. A high $\mathrm{C} / \mathrm{P}$ ratio increases organic acid production (Wang et al. 2004).

According to Whitelaw (2000) and Yadav et al. (2011b), the effectiveness of phosphate-solubilizing microbes is not only caused by their ability to increase the availability of phosphorus but also because of their ability to produce growth-regulating agents such as indole acetic acid (IAA). Indole acetic acid is a growth regulator that functions in cell enlargement and division, to lengthen roots, resistance to stress factors, biosynthesis of various metabolites, stimulation of nitrogen fixation, and increase rate of xylem formation (Khan et al. 2014). All phosphatesolubilizing fungi isolates produce IAA with varying amounts between isolates, of which five selected isolates were the most IAA producers (Table 3 ).

\section{Identification of selected isolates}

Based on morphological identification, the five isolates belong to the genus Aspergillus were observed in the present study (Figure 2). The five fungal isolates showed similar characters, as were colony has dark brown to blackish colored colonies with 0.5 to 4 in size. All isolates had a round black conidial head with a dark brown to black layer of conidiophores (Gilman 1971; Gandjar et al. 1999; Gautam et al. 2012). Aspergillus is a phosphatesolubilizing fungus that is widely isolated from the rhizosphere of various types of plants (sugar cane, tomato, cabbage, asparagus, maize, piper betel) (Alam et al. 2005; Oliveira et al. 2009; Tallapragada \& Seshachala 2012; Ruangsanka 2014; Elias et al. 2016). They are also known for their high ability to dissolve phosphate. The genus Aspergillus produces is economically important growth regulators such as indole acetic acid, which are widely used in fermentation process including producing organic acids (Khan et al. 2007; Sharma et al. 2013) and biosurfactants and also in producing enzymes (Reddy et al. 2014). Filamentous fungi particularly black Aspergillus have been reported for various properties of biotechnological importance such as biocontrol, biodegradation, phosphatesolubilization, and biofertilizer (Yadav et al. 2011b).
Based on molecular identification, the five isolates of phosphate-solubilizing fungi have $100 \%$ similarity with Aspergillus niger (Table 4). A. niger is one of the fungi with high phosphate dissolving capability so that it has the potential to be used as a biofertilizer and biocontrol agent (Das et al. 2013; Ruangsanka 2014; Islam et al. 2019). A. niger a filamentous fungus that belongs to the class Ascomycetes, is a member microbial community in the soil and producer of citric acid (Rashid 2004). A. niger has an important role in the global carbon cycle (Gautam et al. 2011). These microbes are saprophytic and involved in the process of decomposition of organic material containing lignocellulose (Baker 2006).

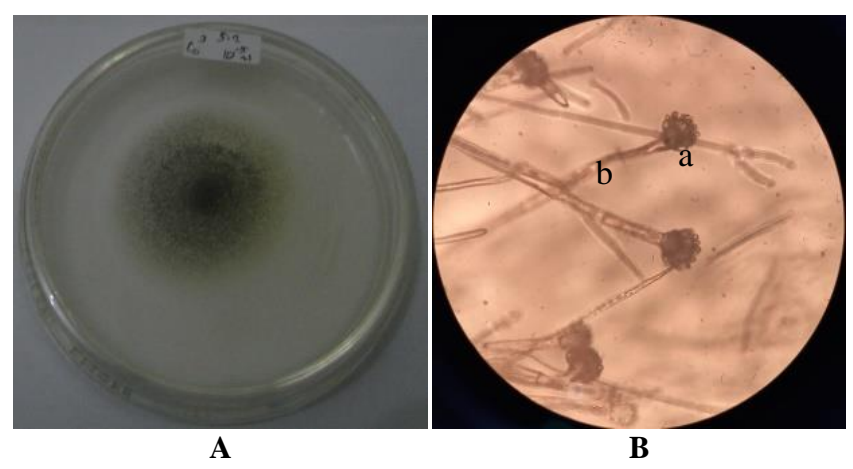

Figure 2. A. Phosphate-solubilizing fungi (Aspergillus) on Pikovskaya medium, B. Microscopic structures of Aspergillus, a. conidia, b. conidiophores.

Tabel 4. Molecular identification of phosphate-solubilizing fungi

\begin{tabular}{llc}
\hline Isolate code & Species identified & Similarity $(\%)$ \\
\hline FG5 & Aspergillus niger & 100 \\
FG8 & Aspergillus niger & 100 \\
FG9 & Aspergillus niger & 100 \\
FG11 & Aspergillus niger & 100 \\
FG12 & Aspergillus niger & 100 \\
\hline
\end{tabular}

Table 3. Types and amounts of organic acids and indole acetic acid production by phosphate-solubilizing fungi isolates

\begin{tabular}{|c|c|c|c|c|c|c|c|}
\hline \multirow{2}{*}{$\begin{array}{c}\text { Isolate } \\
\text { code }\end{array}$} & \multicolumn{6}{|c|}{ Concentration of organic acids $(\mathrm{mg} / \mathrm{kg})$} & \multirow{2}{*}{$\begin{array}{c}\text { Indole acetic acic } \\
(\mathrm{mg} / \mathrm{kg})\end{array}$} \\
\hline & Citric & Oxalate & Malic & Acetate & Butyric & Lactate & \\
\hline FG1 & - & 0.566 & 0.237 & - & 0.626 & - & 1.415 \\
\hline FG2 & 0.549 & 0.524 & - & - & 1.066 & 1.272 & 0.624 \\
\hline FG3 & 0.505 & 0.084 & - & 1.374 & 1.602 & 0.084 & 1.798 \\
\hline FG4 & - & 0.183 & 0.168 & - & 1.479 & 0.244 & 0.615 \\
\hline FG5 & 0.477 & 0.058 & 0.063 & 0.190 & 1.109 & - & 1.985 \\
\hline FG6 & - & - & - & - & 1.136 & - & 1.297 \\
\hline FG7 & - & 0.490 & - & 1.087 & 1.241 & - & 0.624 \\
\hline FG8 & 0.230 & 1.033 & - & 0.164 & 1.188 & - & 1.819 \\
\hline FG9 & 1.109 & 0.477 & 0.063 & 0.190 & 0.058 & - & 2.004 \\
\hline FG10 & 0.058 & - & - & 0.446 & 0.792 & - & 1.521 \\
\hline FG11 & 1.574 & 0.145 & - & 0.979 & 1.519 & - & 2.597 \\
\hline FG12 & 0.606 & 0.621 & 0.045 & 0.526 & 1.648 & 0.247 & 2.129 \\
\hline
\end{tabular}

Note: -: not detected 
Selected phosphate-solubilizing fungi isolated from peat soil have the potential to be used on acid soils, because quantitatively they can dissolve $\mathrm{P}$ from $\mathrm{AlPO}_{4}$ and $\mathrm{FePO}_{4}$. Usually, acid soils rich in $\mathrm{Al}^{3+}$ and $\mathrm{Fe}^{3+}$ (Havlin et al. 1999). In acidic soils, $\mathrm{Al}$ and $\mathrm{Fe}$ fix $\mathrm{P}$ nutrients so that their availability becomes low for plants. Phosphorus fixation causes the use of $\mathrm{P}$ fertilizer to be inefficient, so it is often given in high doses (Havlin et al. 1999; Schroder et al. 2011). Utilization of phosphate-solubilizing fungi makes it possible to increase the efficiency of $\mathrm{P}$ fertilizer use (Sharma et al. 2013). Therefore, the five isolates of Aspergillus niger can be used as biological fertilizers for the management of soil fertility and sustainable crop production.

\section{REFERENCES}

Acevedo E, Castaneda TG, Prada F, Navia M, Romero HM. 2014 Phosphate-solubilizing microorganisms associated with the rhizosphere of oil palm (Elaeis guineensis Jacq.) in Colombia. Appl Soil Ecol 80: 26-33. DOI: 10.1016/j.apsoil.2014.03.011.

Agus F, Subiksa IGM. 2008. Peatlands: Potential for agriculture and environmental aspect. Soil Research Institute and World Agroforestry Center (ICRAF). Bogor, Indonesia. [Indonesian]

Alam S, Khalil S, Ayub N, Rashid M. 2002. In vitro solubilization of inorganic phosphate by phosphate solubilizing microorganism (PSM) from maize rhizosphere. Intl J Agric Biol 4: 454-458.

Anand K, Kumari B, Mallick MA. 2016. Phosphate solubilizing microbes: An effective and alternative approach as biofertilizers. Int J Pharm Pharm Sci 8 (2): 37-40.

Baker SE. 2006. Aspergillus niger genomics: Past, present and into the future. Med Mycol 44: S17-S21. DOI: 10.1080/13693780600921037.

Bashan Y, de-Bashan LE, Prabhu SR, Hernandez JB. 2013. Advances in plant growth-promoting bacterial inoculant technology: formulations and practical perspectives (1998-2013) (1998-2013). Plant Soil 378 $1-33$.

Bric JM, Bostock RM, Silverstone SE. 1991. Rapid in situ assay for indole acetic acid production by bacteria immobilized on a nitrocellulose membrane. Appl Environ Microbiol 57 (2): 535-538.

Chang CH, Yang SS. 2009. Thermo-tolerant phosphate solubilizing microbes for multi-functional biofertilizer preparation. Bioresour Technol 100 (4): 1648-1658. DOI: 10.1016/j.biortech.2008.09.009.

Chatli AS, Beri V, Sidhu BS. 2008. Isolation and characterization of phosphate solubilizing microorganisms from the cold desert habitat of Salix alba Linn. In trans-Himalayan region of Himachal Pradesh. Indian J Microbial 48: 267-273. DOI: 10.1007/s12088-008-0037-y.

Das A, Dutta B, Barooah AK. 2013. In vitro solubilization of inorganic phosphate by phosphate solubilizing fungi isolated from tea Agroecosystem soil of Barak Valley, Southern Assam. Intl J Microbiol Res 4 (3): 336-341.

El-Azouni IM. 2008. Effect of phosphate solubilizing fungi on growth and nutrient uptake of soybean (Glycine $\max$ L.) plants. J Appl Sci Res 4: 592-598.

Elias F, Woyessa D, Muleta D. 2016. Phosphate solubilization potential of rhizosphere fungi isolated from plants in Jimma Zone, Southwest Ethiopia. Intl J Microbiol 2016: 5472601. DOI: 10.1155/2016/5472601.

Gandjar I, Samson RA, van den Tweel-Vermeulen K, Oetari A, Santoso I. 1999. Introduction of General Tropical Fungi. University of Indonesia. Depok. [Indonesian]

Gao L. Kong F, Feng C, Wang J, Gao J, Shen G, Zhang C. 2016. Isolation, characterization, and growth promotion of phosphate solubilizing bacteria associated with Nicotiana tabacum (Tobacco). Pol J Environ. Stud 25 (3): 993-1003. DOI: 10.15244/pjoes/61820.

Gaur AC, Mathur RS, Sadasivam KV. 1980. Effect of organic material and phosphate-dissolving culture on the yield of wheat and green gram. Indian J Agron 25: 501-503.

Gautam AK, Bhadauria R. 2012. Characterization of Aspergillus species associated with commercially stored Triphala powder. African J Biotechnol 11 (104): 16814-16823. DOI:10.5897/AJB11.2311.
Gautam AK, Sharma S, Avasthi S, Bhadauria R. 2011. Diversity, pathogenicity and toxicology of A. niger: an important spoilage fungi. Res J Microbiol 6 (3): 270-280. DOI: 10.3923/jm.2011.270.280.

Gilman JC. 1971. A Manual of Soil Fungi. The Low a State University Press, USA.

Gizaw B, Tsegay Z, Tefera G, Aynalem E, Wassie M, Abatneh E. 2017. Phosphate solubilizing fungi isolated and characterized from Teff rhizosphere soil collected from North Showa and Gojam, Ethiopia. J Fertil Pestic 8: 180. DOI: 10.4172/2471-2728.1000180.

Goenadi D, Siswanto H, Sugiarto Y. 2000. Bioactivation of poorly soluble phosphate rocks with a phosphorus solubilizing fungus. Soil Sci Soc Am J 64: 927-932.

Gupta N, Sabat J, Parida R, Kerkatta D. 2007. Solubilization of tricalcium phosphate and rock phosphate by microbes isolated from chromite, iron, and manganese mines. Acta Bot Croat 66 (2): 197-204.

Gyaneshwar P, Kumar GN, Parekh LJ, Poole PS. 2002. Role of soil microorganism in improving $P$ nutrition of plants. Plant Soil 245: 8393. DOI: 10.1023/A:1020663916259.

Havlin JL, Beaton JD, Tisdale SL, Nelson WL. 1999. Soil Fertility and Fertilizers. An Introduction to Nutrient Management. $6^{\text {th }}$ ed. PrenticeHall, New Jersey.

Hou E, Tang S, Kuang Y, Lu X, Heenan M, Wen D. 2018. Solubility of phosphorus in subtropical forest soil as influenced by low molecular organic acids and key soil properties. Geoderma 313: 172-180. DOI: 10.1016/j.geoderma.2017.10.039.

Hue NV, Craddock GR, Adamet F. 1986. Effect of organic acids on aluminum toxicity in subsoils. Soil Sci Am J 50: 28-34. DOI: 10.2136/sssaj1986.03615995005000010006x.

Illmer P, Schinner F. 1995. Solubilization on inorganic calcium phosphate: Solubilization mechanisms. Soil Biol Biochem 27 (3): 257-263. DOI: 10.1016/0038-0717(94)00190-C

Islam MK, Sano A, Majumder MSI, HossainMA, Sakagami JI. 2019. Isolation and molecular characterization of phosphate solubilizing filamentous fungi from subtropical soils in Okinawa. Appl Ecol Environ Res 17 (4): 9145-9157.

Kang SC, Ha CG, Lee TG, Maheshwari DK. 2002. Solubilization of insoluble inorganic phosphate by a soil-inhabiting fungus Fomitopsis sp. PS 102. Curr Sci 82: 439-441.

Khan AA, Jilani G, Akhtar MS, Nagvi SM, Rasheed M. 2009. Phosphorus solubilizing bacteria: Occurrence, mechanisms, and their role in crop production. J Agric Biol Sci 1 (1): 48-58.

Khan MS, Zaidi A, Ahmad E. 2014. Mechanism of phosphate solubilization and physiological function of phosphate-solubilizing microorganisms. In: Khan MS, Zaidi A, Musarrat J (eds). Phosphate Solubilizing Microorganisms: Principles and Application of Microphore Technology. Springer, Cham.

Khan MS, Zaidi A, Wani PA. 2007. Role of phosphate-solubilizing microorganisms in sustainable agriculture- A review. Agron Sustain Dev 27: 29-43. DOI: 10.1051/agro:2006011.

Mahamuni SV, Wani PV, Patil AS. 2012. Isolation of phosphate solubilizing fungi from rhizosphere of sugarcane and sugar beet using TCP and RP solubilization. Asian J Biomed Pharmaceut Sci 2 (1): 237-244.

Mahidi SS, Hassan GI, Hussain A, Faisul-ur-Rasool. 2011. Phosphorus availability issue-Its fixation and role of phosphate solubilizing bacteria in phosphate solubilization-Case study. Res J Agric Sci 2: 174-179.

Malviya J, Singh K, Joshi V. 2011. Effect of phosphate solubilizing fungi on growth and nutrient uptake of ground nut (Arachis hypogaea) plants. Adv Biores 2 (2): 110-113.

Mardad I, Serrano A, Soukri A. 2014. Solubilization of inorganic phosphate and production of organic acids by bacteria isolated from a Moroccan mineral phosphate deposit. Afr J Microbial Res 7 (8): 626635. DOI: 10.5897/AJMR12.1431.

Nahas E. 1996. Factors determining rock phosphate solubilization by microorganisms isolated from soil. World J Microb Biotechnol 12: 18-23. DOI: 10.1007/BF00327716.

Nurulita Y, Adetutu EM, Gunawan H, Zul D, Ball AS. 2016. Restoration of tropical peat soil: The application of soil microbiology for monitoring the success of the restoration process. Agric Ecosyst Environ 216: 293-303. DOI: 10.1016/j.agee.2015.09.031.

Oliveira CA, Alves VMC, Mariel IE, Gomes EA, Scotti MR, Carneiro NP, Gumaires CT, Scaffert RE, Sa NMH. 2009. Phosphate solubilizing microorganisms isolated from rhizosphere of maize cultivated in an Oxisol of Brazilian Cerrado Biome. Soil Biol Biochem 41 (9): 1782-1787. DOI: 10.1016/j.soilbio.2008.01.012. 
Omar SA. 1998. The role of rock phosphate solubilizing fungi and Vesicular arbuscular Mycorrhiza (VAM) in growth of wheat plants fertilized with rock phosphate. World J Microbial Biotechnol 14: 211 218. DOI: $10.1023 / \mathrm{A}: 1008830129262$

Panda B, Rahman H, Panda J. 2016. Phosphate solubilizing bacteria from the acidic soils of Eastern Himalayan region and their antagonistic effect on fungal pathogen. Rhizosphere 2: 62-71. DOI: 10.1016/j.rhisph.2016.08.001.

Pradhan N, Sukla LB. 2005. Solubilization of inorganic phosphates by fungi isolated from agricultural soil. Afr J Biotechnol 5 (10): 850-854

Rashid M, Khalil S, Ayub N, Alam S, Latif F. 2004. Organic acids production and phosphate solubilization by phosphate solubilizing microorganisms (PMS) under in vitro conditions. Pak J Biol Sci 7 (2): 187-196. DOI: 10.3923/pjbs.2004.187.196.

Reddy PLN, Babu BS, Radhaiah A, Sreeramulu A. 2014. Screening, identification, and isolation of cellulolytic fungi from soils of Chittoor District, India. Intl J Curr Microbiol App Sci 3(7): 761-771.

Rodriguez H, Fraga R. 1999. Phosphate solubilizing bacteria and their role in plant growth promotion. Biotechnol Adv 17: 319-339. DOI: 10.1016/S0734-9750(99)00014-2.

Ruangsanka S. 2014. Identification of phosphate solubilizing fungi from the asparagus rhizosphere as antagonist of the root and crown rot pathogen Fusarium oxysporum. Science Asia 40: 16-20. DOI: 10.2306/scienceasia1513-1874.2014.40.016.

Ryan PR, Delhaize E, Jones DL. 2001. Function and mechanisms of organic anion exudation from plant roots. Ann Rev Plant Physiol Plant Mol Biol 52: 527-560. DOI: 10.1146/annurev.arplant.52.1.527.

Schroder JL, Zhang HL, Girma K, Raun WR, Penn CJ, Payton ME. 2011 Soil acidification from long-term use of nitrogen fertilizers on winter wheat. Soil Sci Soc Am J 75: 957-964. DOI:10.2136/sssaj2010.0187.

Sharma BC, Rao S, Saha A. 2012. In vitro solubilization of tricalcium phosphate and production of IAA by phosphate solubilizing bacteria isolated from tea rhizosphere of Darjeeling Himalaya. Plant Sci Feed 2 (6): 96-99.

Sharma SB, Sayyed RZ, Trivedi MH, Gobi TA. 2013. Phosphate solubilizing microbes: sustainable approach for managing phosphorus deficiency in agricultural soils. Springerplus 2: 587 . DOI: 10.1186/2193-1801-2-587.

Soekardi M, Hidayat A. 1988. Extent and distribution of peat soils of Indonesia. Third meeting cooperative research on problem soils. CRIFC. Bogor.
Tallapragada P, Seshachala U. 2012. Phosphate solubilizing microbes and their occurrence in the rhizosphere of Piper betel in Karnataka, India. Turk J Biol 36: 25-25. DOI:10.3906/biy-1012-160

Vassileva MN, Vassilev N, Azcon R. 1998. Rock phosphate solubilizing by Aspergillus niger on olive cake-based medium and its further application in a soil-plant system. World. J. Microbiol. Biotechnol. 14: 281-284. DOI: 10.1023/A:1008858802855.

Walpola BC, Yoon MH. 2012. Prospectus of phosphate solubilizing microorganisms and phosphorus availability in agricultural soils: A review. Afr J Microbial Res 6 (37): 6600-6605. DOI: 10.5897/AJMR12.889.

Wang G, Zhou KQ, Jin J, Pan XW, Zhao Y. 2004. Effect of different C sources on the solubilization of rock phosphate by three phosphate solubilizing fungi (PSF). Chinese J Ecol 23: 32-36.

Wei Y, Zhao Y, Shi M, Cao Z, Lu Q, Yang T, Fan Y, Wei Z, 2018. Effect of organic acids production and bacterial community on the possible mechanism of phosphorus solubilization during composting with enriched phosphate solubilizing bacteria inoculation. Bioresour Technol 247: 190-199. DOI: 10.1016/j.biortech.2017.09.092.

Whitelaw MA. 2000. Growth promotion of plants inoculated with phosphate solubilizing fungi. Adv Agron 69: 99-151. DOI: 10.1016/S0065-2113(08)60948-7.

Yadav J, Verma JP, Tiwari KN. 2011a. Solubilization of tricalcium phosphate by fungus Aspergillus niger at different carbon sources and salinity. Trends Appl Sci Res 6 (6): 606-613. DOI: 10.3923/tasr.2011.606.613.

Yadav J, Verma JP, Tiwari KN. 2011b. Plant growth-promoting activities of fungi and their effect on chickpea plant growth. Asian J Biol Sci 4 (3): 291-299. DOI: 10.3923/ajbs.2011.291.299.

Yasmin H, Bano A. 2011. Isolation and characterization of phosphate solubilizing bacteria from rhizosphere soil of weeds of Khewra salt range and Attock. Pak J Bot 43(3): 1663-1668.

Yasser MM, Mousa ASS, Massoud ON, Nash SH. 2014. Solubilization of inorganic phosphate by phosphate solubilizing fungi isolated from Egyptian Soils. J Biol Earth Sci 4 (1): B83-B90.

Zang Y, Chen FS, Wu XQ, Luan FG, Zhang LP, Fang XM, Wan SZ, Hu XF, Ye JR. 2018. Isolation and characterization of two phosphatesolubilizing fungi from rhizosphere soil of Moso bamboo and their functional capacities when exposed to different phosphorus sources and $\mathrm{pH}$ environment. PLoS ONE 13 (7): e0199625. DOI: 10.1371/journal.pone.0199625. 